\title{
PERFORMANCE OF ISLAMIC MICROCREDIT IN PERSPECTIVE OF MAQASID AL-SHARIAH: A CASE STUDY ON AMANAH IKHTIAR MALAYSIA
}

\author{
Md. Mahmudul Alam, Ph.D. \\ Institute for Environment and Development (LESTARI) \\ National University of Malaysia (UKM) \\ Bangi, Selangor, Malaysia \\ Email: rony000@gmail.com \\ Mobile: +60182467050 \\ (Corresponding author) \\ Jamaliah Said, Ph.D. \\ Accounting Research Institute/Faculty of Accountancy \\ Universiti Teknologi MARA (UiTM) \\ Shah Alam, Selangor, Malaysia \\ Email: jamaliah533@salam.uitm.edu.my \\ Salwana Hassan, Ph.D. \\ Accounting Research Institute/Faculty of Business Management \\ Universiti Teknologi MARA (UiTM) \\ Shah Alam, Selangor, Malaysia \\ Email: salwana@salam.uitm.edu.my
}

\section{Citation Reference:}

Alam, M.M., Said, J., and Hassan, S. 2015. Performance of Islamic Microcredit in Perspective of Maqasid Al-Shariah: A Case Study on Amanah Ikhtiar Malaysia. Humanomics. Vol. 31(4), pp.374 - 384. [Online Link] 


\title{
PERFORMANCE OF ISLAMIC MICROCREDIT IN PERSPECTIVE OF MAQASID AL-SHARIAH: A CASE STUDY ON AMANAH IKHTIAR MALAYSIA
}

\author{
Jamaliah Said \\ Md. Mahmudul Alam \\ Salwana Hassan
}

\begin{abstract}
Many studies have evaluated the role of microcredit programs using the conventional assessment approach. However, the conventional system of socioeconomic role assessment cannot evaluate the performance of Islamic microcredit in terms of achieving the objectives of Shariah for the Islamic microcredit model. Therefore, this study examines the role of Islamic microcredit based on the achievement of Maqasid Al-Shariah. It uses primary data that were collected through a questionnaire survey distributed among 393 microcredit borrowers from Amanah Ikhtiar Malaysia (AIM). The survey was conducted from July 2013 to December 2013 in the State of Sabah and in Peninsular Malaysia. This research also analyzes the socioeconomic roles and the achievement of microcredit and microenterprise from the perspective of the five principles of Al-daruriyyat from Maqasid Al-Shariah. Results indicate that the microcredit program of AIM has a positive and enhancing effect on the livelihood of clients. This effect is reflected in the assessment of their well-being, especially in the context of Maqasid Al-Shariah.
\end{abstract}

Key Words: Amanah Ikhtiar Malaysia, Islamic microcredit, microenterprise, Maqasid AlShariah, Al-daruriyyat

\section{Introduction}

Islam provides a set of principles, regulations, and laws that are collectively known as Shariah. According to Islamic belief, Shariah has a common objective (Maqasid) that seeks the betterment (Masalih) of mankind under a divine (one god: Allah) guideline. Therefore, the term Maqasid Al-Shariah refers to the objectives of Islamic law. This law answers the question of "why", such as "why do we need to pay Zakat?" and "why do we need to avoid interest?"

Dusuki and Bouheraoua (2011) defined Maqasid Al-Shariah as the ultimate objective of Islamic law that serves the interests of all human beings (Maslahah). They added that such laws are designed to protect the interest of human life on earth and the life thereafter, as well to improve and perfect life. Maqasid Al-Shariah cares not only for Muslims but also mankind as a whole to suit the modernization of human needs.

Theoretically, the principle of Maqasid Al-Shariah is similar to Maslow's hierarchy theory, in which the physiological needs are placed on the bottom while the need for selfactualization is on top (Ahmed et al., 2011; Bakar \& Ghani, 2011). The prominent Islamic scholars Al-Shatibi and Al-Ghazali constructed the principle of Maqasid Al-Shariah and divided human needs into three main hierarchy levels, namely, Al-daruriyyat, Al-hajjiyyat, and Al-tahsiniyyat. Al-daruriyyat, which is at the bottom, refers to the interest of life upon which people essentially depend, Al-hajjiyyat corresponds to the interests that supplement the essential interest, and Al-tahsiniyyat denotes the interest that leads to the refinement and 
perfection of the customs and conduct of the people at all levels of achievement when it is realized.

Many studies have evaluated the role of the Islamic microcredit program using the conventional assessment approach. However, the conventional system of socioeconomic assessment cannot evaluate the performance of this program in terms of achieving the holistic objectives of Shariah for the Islamic microcredit model. Therefore, the current study examines the role of Islamic microcredit based on the achievement of Maqasid Al-Shariah. Previous scholars, such as Dar (2004), have also justified Maqasid Al-Shariah as a suitable theory to be used for analysis and measurement in empirical studies.

\section{Microcredit Program in Malaysia}

In Malaysia, the eradication of poverty is the main agendum since the country gained its independence in 1957. This objective is also the main motivation of the New Economic Policy, which was introduced in 1970 to reduce poverty by increasing income levels and employment opportunities for all Malaysians. As a result, the poverty rate in Malaysia has decreased from 52.4\% in 1970 to 3.8\% in 2009. The 10th Malaysia Plan (2010 to 2015) also planned to achieve an average of 40\% income growth in households, from RM 1440 in 2009 to RM 2300 in 2015 . Furthermore, it also aims to reduce the poverty rate to $2.0 \%$ in 2015 (EPU, 2010).

The establishment of a microcredit institution is a way to improve the standard of living of the poor. Microfinance refers to the provision of a broad range of financial services, such as savings, credit, insurance, and payment services, to the poor or to the members of the low-income group who are excluded from normal banking sectors (Nawai \& Shariff, 2011). Since 1987, the microfinance program has been implemented in Malaysia as a poverty eradication strategy. Malaysia currently has three large microfinance institutions, namely, Amanah Ikhtiar Malaysia (AIM), Tabung Ekonomi Kumpulan Usaha Niaga (TEKUN), and Perbadanan Usahawan Nasional Berhad (PUNB). Each institution targets different groups of people.

AIM is the first microfinance institution in Malaysia and is the largest Grameen Bank replication outside Bangladesh (McGuire, Conroy, \& Thapa, 1998). This institution was developed in 1988 under the Trustee Incorporation Act 258 (revised in 1981) (Chamhuri \& Quinones, 2000).

AIM started out as a pilot project of the Center for Policy Research of the Universiti Sains Malaysia (USM), whose main objective was to reduce the number of poor households in the country by financing income-generating activities via the disbursement of Ikhtiar Funds to these households (AIM, 2012). As of September 2012, AIM has 123 branches all over Malaysia, with a total of 322,022 borrowers/ clients/Sahabat. AIM serves nearly $84 \%$ of the total poor and extremely poor households in this country, and it has achieved a remarkable repayment rate of $99.54 \%$ (AIM, 2012).

Several Malaysian studies have attempted to analyze the role of AIM in poverty alleviation. Gibbons and Kassim (1990) observed a significant increase in the monthly household income of several clients following their participation in the microcredit schemes of AIM. The Social Science and Economic Research Unit (SERU) of the Prime Minister Department conducted a study in 1991 and obtained similar results. The overall household 
income of households increased significantly per month from RM 197.78 to RM 465.66 after joining the AIM program. SERU (1991) also examined the effect of AIM on the life quality, household assets, agricultural land, and household savings. Moreover, the overall financial performance of AIM participants was better than that of non-participants as per a comparison of the household incomes, expenses, savings, and assets of the former with those of the latter (Salma, 2004). Omar, Noor, and Dahalan (2012) suggested that AIM alleviates poverty in Malaysia by increasing the household income of clients.

TEKUN was established in 1998 and was renamed from TEKUN Nasional Foundation to TEKUN Nasional in 2008 through a rebranding and repositioning exercise. The objective of this institution is to provide simple and quick financing facilities to bumiputeras to kickstart and to expand their businesses further. TEKUN Nasional generates business and income-generating opportunities, capital, guidance, support, and networking platforms for entrepreneurs (TEKUN, 2013).

PUNB serves as the national entrepreneur development corporation of Malaysia. It was established in July 1991 with the mission of providing opportunities and financial and corporate support to Bumiputera entrepreneurs to facilitate business success (PUNB, 2013). This institution also aims to increase the quantity and enhance the quality of small and medium-sized Bumiputera entrepreneurs in the industrial, retail, and commercial sectors.

\section{Methodology}

The study data were collected through a questionnaire guide distributed from July 2013 to December 2013. A total of 393 samples were collected from current and old AIM clients in seven branches, namely, Beaufort (Sabah), Kota Belud (Sabah), Sik (Kedah), Besut (Terengganu), Kuala Selangor (Selangor), Hulu Perak (Perak), and Mini Tanjung Malim (Perak). The distribution of the sample among these centers and branches are shown in Table 1.

Table 1: Distribution of the Sample based on Center and Branch.

\begin{tabular}{|c|c|c|c|c|}
\hline No. & Branch & Center & $\begin{array}{c}\text { Total } \\
\text { Number of } \\
\text { Respondents }\end{array}$ & $\begin{array}{c}\text { Total } \\
\text { Number of } \\
\text { Branches }\end{array}$ \\
\hline \multirow{2}{*}{1} & \multirow{2}{*}{ Beaufort } & As Solehah & 35 & \multirow{2}{*}{73} \\
\hline & & Nurulshamsi & 38 & \\
\hline \multirow{4}{*}{2} & \multirow{4}{*}{ Kota Belud } & Seri Ayu & 26 & \multirow{4}{*}{78} \\
\hline & & Nur Syafiqah & 23 & \\
\hline & & Syafirah & 17 & \\
\hline & & Nur Atiqa & 12 & \\
\hline \multirow{3}{*}{3} & \multirow{3}{*}{ Sik } & Sri Melati & 39 & \multirow{3}{*}{79} \\
\hline & & Darul Salam & 31 & \\
\hline & & Chop Chai & 8 & \\
\hline \multirow{5}{*}{4} & \multirow{5}{*}{ Besut } & Darul Hana & 27 & \multirow{5}{*}{86} \\
\hline & & Nurhidayah & 27 & \\
\hline & & Mawardah & 12 & \\
\hline & & Ilham Sanubari & 12 & \\
\hline & & Al Basyir & 8 & \\
\hline 5 & Kuala Selangor & Sri Nur Fadilah & 22 & 22 \\
\hline \multirow{2}{*}{6} & Hulu Perak & Mahligai & 13 & \multirow{2}{*}{33} \\
\hline & (Mini Lenggong) & Seri Murni & 8 & \\
\hline
\end{tabular}




\begin{tabular}{|c|c|c|c|c|}
\hline & & $\begin{array}{l}\text { Nurul Amin } \\
\text { Nurul Fatehah } \\
\text { Nasihah }\end{array}$ & $\begin{array}{l}5 \\
6 \\
1 \\
\end{array}$ & \\
\hline 7 & $\begin{array}{c}\text { Batang Padang } \\
\text { (Mini Tanjung Malim) }\end{array}$ & Khidmat Yunus & 23 & 23 \\
\hline & \multicolumn{2}{|c|}{ Total Sample } & 393 & 393 \\
\hline
\end{tabular}

The primary data were processed via the change assessment and scoring tool (CAST), which consists of five scales, namely, "very negative" (1), "negative" (2), "no change" (3), "positive" (4), and "very positive" (5). CAST was developed in the mid-1990s as a special focus group technique to capture the perceptions of change by people. This method was effectively adopted by Mikkelsen et al. (2008) to evaluate the variation, that is, the reduction in the level of poverty with the implementation of the Swedish Development Assistance Program.

This study analyzed the data based on the achievement of the five principles of $\mathrm{Al}$ daruriyyat from the perspective of Maqasid Al-Shariah. Al-daruriyyat refers to the essential need of humans, which serves as a basis for the establishment of welfare in this world and in the life hereafter. If this need is ignored, then coherence and order cannot be established, thereby resulting in total loss in the life hereafter. Al-daruriyyat has five basic principles (Seitanidi \& Crane, 2009; Dusuki \& Bouheraoua, 2011), which are explained as follows:

1. Religion (Ad-Din) - Every Muslim must worship Allah (s.w.t) and seek truth and justice. This principle must be preserved in all circumstances.

2. Life (Al-Nafs) - Respect for human life must be observed by preserving and protecting it at all times. The human existence must be held in high regard, and human well-being must not be violated.

3. Intellect $(A l-A q l)$ - Right or wrong behavior/associations are discerned through freedom of thought, assembly, and speech. Shariah encourages questing for knowledge to ensure the intellectual development of Muslims.

4. Lineage/honor (Al-Nasb) - Duty and legal obligations must be performed to respect the human community based on the sacredness of life (as reflected in future generations).

5. Wealth (Al-Mal) - Economic justice, especially in terms of creating money and wealth, must be enacted as an alternative to the previous wage system.

\section{Findings and Discussion}

\section{Socioeconomic Status}

\section{Household Size}

Among the respondents, $68.87 \%$ of the respondents has more than five family members, whereas $20.39 \%$ has five. Most clients of the Kota Belud, Hulu Perak, and Batang Padang branches belong to average households composed of four, seven, and two family members, respectively.

\section{Education}

Among the respondents, approximately $30 \%$ indicated that they had no formal education. Among the literate respondents, $25.07 \%$ had at least achieved elementary schooling (Ujian 
Pencapaian Sekolah Rendah), whereas $22.59 \%$ indicated Sijil Pelajaran Malaysia as their highest educational attainment. Another $20.11 \%$ indicated that they had Penilaian Menengah Rendah/Sijil Rendah Pelajaran-level education, while $1.65 \%$ possessed at least Sijil Tinggi Persekolahan Malaysia qualification. The remaining $0.55 \%$ had diplomas.

Income from Non-Microenterprise Sources

A total of $15.7 \%$ of the respondents received most of their income from sources other than economic activities from microcredit. In other instances, the income of the poor does not originate from a single source, but from various sources, such as the government, Zakat institutions, Waqaf institutions, and non-governmental organizations. Among these respondents, $8.5 \%$ received their income from Bantuan Rakyat 1 Malaysia, $5.79 \%$ from Jabatan Kebajikan Masyarakat, 3.31\% from the cost of living assistance, 2.48\% from schools, $1.38 \%$ from Kumpulan Wang Amanah Pelajar Miskin, 1.38\% from Zakat, 1.38\% from senior citizen assistance, $1.1 \%$ from E-KASIH, 0.83\% from Projek Perumahan Rakyat Miskin Tegar, and the remaining $1.1 \%$ from other sources.

In addition, some of the respondents received annual assistance in the form of food from the Masjid community and from Orang Kaya Kampung. The victims of natural disasters also received aid from AIM. Based on the interviews, only $10 \%$ of the respondents did not receive any form of financial aid.

Savings

Among the respondents, a total of $52.07 \%$ reports current savings of less than RM 10,000, $2.20 \%$ saves between RM 10,001 and RM 20,000 monthly, 1.93\% saves between RM 20,001 and RM 30,000 monthly, and $43.80 \%$ of the respondents reports no current savings.

Ownership of Assets

The majority of the respondents $(65.01 \%)$ do not own land. Among the respondents who do, $32.51 \%$ possesses less than 10 acres of land, $1.93 \%$ has 11 acres to 20 acres, $0.28 \%$ owns 21 acres to 30 acres, and $0.28 \%$ possesses 31 acres to 40 acres.

The majority of the respondents $(79.61 \%)$ does not declare jewelry as assets. Among those respondents who do, $18.18 \%$ owns jewelry worth less than RM 10,000, $1.38 \%$ has jewelry whose worth ranges between RM 10,001 and RM 20,000, and $0.84 \%$ possesses jewelry worth RM 20,001 and above.

The majority of the respondents $(54.27 \%)$ owns vehicles as a medium of transportation. Among these respondents, $21.76 \%$ possesses cars, $20.66 \%$ owns motorcycles, $6.06 \%$ owns boats, $2.20 \%$ owns vans, $1.93 \%$ owns lorries, $0.83 \%$ owns machines, and $0.28 \%$ owns other transport media, such as bicycles, taxis, and mixed vehicles.

\section{Performance of Microcredit}

Year of Involvement

Among the respondents, $37.40 \%$ had joined AIM early (i.e., five years to eight years previously), whereas $62.60 \%$ joined AIM since 2006. 
Total Amount of Borrowings

Approximately $66.67 \%$ of the respondents has taken out loans that exceeded RM 20,000 in total (Table 2), 9.37\% has loans that range between RM 5,001 and RM 10,000, 8.54\% has loans that range between RM 10,001 and RM 15,000, 9.09\% has loans that range between RM 15,001 and RM 20,000, and only $6.34 \%$ has loans that amounted to less than RM 5,000. Most of the borrowers who took out relatively large loans joined the scheme early (i.e., five years to eight years previously).

Table 2: Total Amount of Loans Received by Borrowers.

\begin{tabular}{lc}
\hline Amount of Loan Received & Number of Borrowers (\%) \\
\hline Up to RM 5,000 & 6.34 \\
RM 5,001 to RM 10,000 & 9.37 \\
RM 10,001 to RM 15,000 & 8.54 \\
RM 15,001 to RM 20,000 & 9.09 \\
RM 20,001 and above & 66.67 \\
\hline
\end{tabular}

Usage of Loans

Among the respondents, $60 \%$ used their loans for economic activities, $30 \%$ applied them to both productive and non-productive purposes, and the remaining $10 \%$ utilized their loans unproductively, such as in household necessities, medicine, and education.

Repayment of Loans

The majority of the respondents (95.32\%) actively participates in AIM and displays a favorable repayment record. Among the current active members, $60 \%$ has developed a future plan to repay their credit and are not taking on additional credit, while $40 \%$ does not have such plans.

\section{Performance of Microenterprise}

Sources of Finance for Microenterprises

Apart from formal sources of financial assistance, some clients seek funds from other government agencies, such as Skim Bantuan Nelayan (Fisherman's Assistance Scheme). Given that these households cannot earn enough cash from their income-generating activities to cater to urgent needs or to repay debts, they must obtain funds from other sources. This financial assistance helps them grow their businesses, improve their microenterprises, and ensure the success and sustainability of their businesses.

Approximately $20 \%$ of the respondents has personally invested in the microenterprise business. Only $13.77 \%$ of respondents has invested less than RM 5,000, 3.86\% has invested between RM 5,001 and RM 10,000, 1.65\% has invested between RM 10,001 and RM 15,000, $0.83 \%$ has invested between RM 15,001 and RM 20,000, and $0.28 \%$ has invested more than RM 20,000 (Table 3). Therefore, most clients may be operating their businesses as survivalist rather than as growth-oriented micro-businesses.

Table 3: Personal Investments of Borrowers in Microenterprises. 


\begin{tabular}{lc}
\hline Amount of Shares Invested In & No of Borrowers (\%) \\
\hline Up to RM 5,000 & 13.77 \\
RM 5,001 to RM 10,000 & 3.86 \\
RM 10,001 to RM 15,000 & 1.65 \\
RM 15,001 to RM 20,000 & 0.83 \\
RM 20,001 and above & 0.28 \\
No investments & 79.61 \\
\hline
\end{tabular}

Income from Microenterprises

A total of $69.42 \%$ of the respondents does not have any other source of income except from economic activities through microcredit investments or microenterprises. Overall, the majority of the respondents has mainly obtained income from the rubber sector $(18.46 \%)$, agriculture $(12.12 \%)$, business $(8.54 \%)$, fishery (6.34\%), food stalls $(6.06 \%)$, kuih-muih $(5.23 \%)$, paddies $(3.86 \%)$, groceries and poultry $(3.31 \%)$, workshops $(2.75 \%)$, sewing $(2.48 \%)$, palm oil sale $(1.93 \%)$, and sago provision $(1.65 \%)$. Specifically, rubber tapping is the main source of income for clients in Sik, Hulu Perak, and Batang Padang. The clients in Kota Belud and Besut are mainly involved in agricultural activities, those in Kuala Selangor are mainly food vendors, and those in Beaufort are mainly fishermen.

\section{Job Creation}

Approximately $40 \%$ of the respondents mentioned that by applying microcredit, they run their businesses independently. A total of $40 \%$ runs businesses with husbands, and $10 \%$ does not engage in business directly but has other household members perform this task. Therefore, microcredit creates jobs not only for the borrowers but also for their family members. However, the job creation scope of microenterprises is limited outside of family members.

\section{Fulfillment of Maqasid Al-Shariah}

\section{Religion (Ad-Din)}

Changes in religious practices: Among the respondents, $90 \%$ agreed that taking microcredit positively affects their religious practices (Table 4). They also strongly feel that they are have strengthened their commitments to pray at the mosque and to attend religious classes. Some respondents also mentioned recently that participating in the microcredit program enabled them to perform pilgrimages (Hajj).

Table 4: Achievement of the Microcredit Program based on Maqasid Al-Shariah.

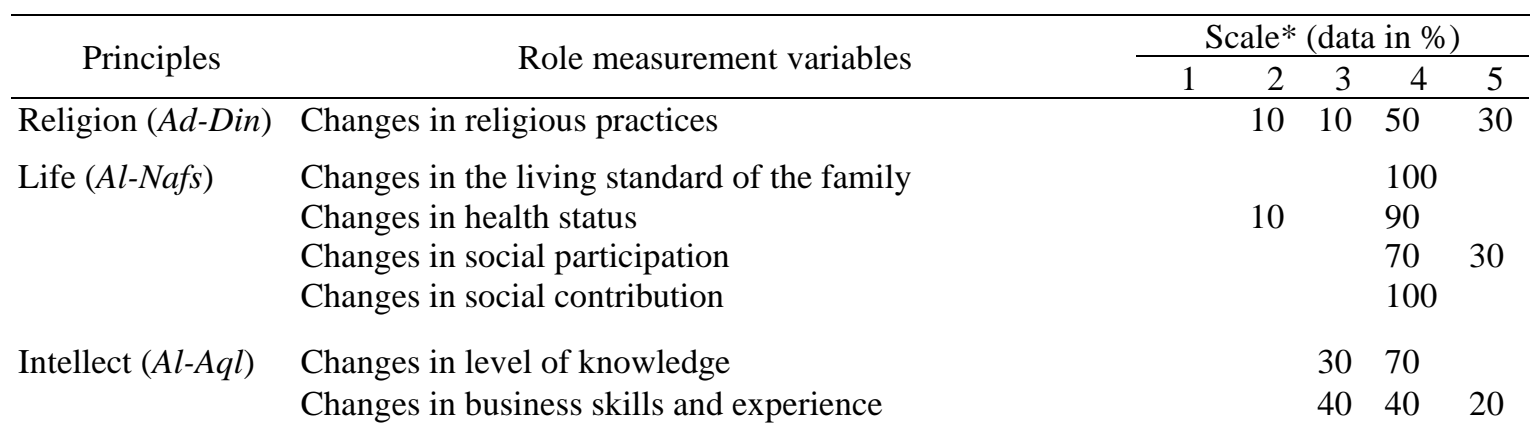


$* 1=$ very negative, $2=$ negative, $3=$ no change, $4=$ positive, $5=$ very positive.

Life (Al-Nafs)

Changes in the living standard of the family: Almost all of the respondents agreed that participating in the microcredit program positively affects their living conditions (Table 4). All of them stated that their living conditions have improved significantly after taking the credit.

Changes in health status: Approximately $90 \%$ of the respondents perceived that the credit they received enables them to control health conditions effectively (Table 4). All of them stated that their present health condition is better than before. However, some of them argued that their health conditions deteriorated because of age.

Changes in social participation: Almost all of the respondents agreed that they are increasingly social at present after taking microcredit (Table 4). The majority of the respondents has established good relationships with neighbors and has participated in society as members in various associations. Their attendance in weekly meetings and collaborations with various groups also improve their interactions with other people in society. Given the skills they gained from their business activities, some respondents have recently been appointed as committee members in their mosques. In fact, one respondent has even been appointed the secretary and unit chief assistant in Pertubuhan Peladang Lenggong. Overall, the confidence of microcredit borrowers to get involved in social activities increased.

Changes in social contribution: Almost all of the respondents agreed that they have contributed to society by engaging in gotong-royong (Table 4). Most gotong-royong activities involved cleaning the housing area in which they live. Some respondents added that they assisted their neighbors in preparing for certain ceremonies, such as weddings, kenduri doa selamat, and kenduri tahlil. Therefore, the respondents are confident to mingle in society and to help their neighbors.

\section{Intellect $(A l-A q l)$}

Changes in level of knowledge: Approximately $70 \%$ of the respondents agreed that participating in the microcredit program has increased their level of knowledge (Table 4). They gained different kinds of knowledge by engaging in several economic activities through credit. However, $30 \%$ of the respondents mentioned that they did not obtain any new knowledge from their activities.

Changes in business skills and experience: Approximately $60 \%$ of the respondents agreed that their involvement in the microcredit program positively affected their business skills and experiences (Table 4). Among them, 20\% demonstrated highly positive changes in this respect. However, $40 \%$ argued that their business skills and experience were unaffected 
because most of them are housewives, have been engaged in the same activity for a long time, or work jobs that do not require a high level of specific skill.

Changes in level of knowledge of the family: Almost all of the respondents agreed that their involvement in the microcredit program positively affected the level of knowledge of their family (Table 4). Among them, 30\% demonstrated highly positive changes in this sense. Many of the respondents are presently able to send their children to school and to higher education institutions.

\section{Lineage/honor (Al-Nasb)}

Changes in lineage/honor among family members: Almost all of the respondents agreed that their involvement in the microcredit program alters the lineage among family members (Table 4). Among these respondents, $40 \%$ demonstrated highly positive changes.

Changes in perception of society: Approximately $80 \%$ of the respondents agreed that the perception of the society with respect to their families positively improved because of their involvement in the microcredit program (Table 4). The majority of the respondents stated that they received increased respect from the society once their living conditions were improved. However, $20 \%$ of the respondents reported no change in the perception of society toward their families.

Wealth $(A l-M a l)$

Changes in monthly household income: Almost all of the respondents agreed that their monthly household income has increased as a result of their involvement in the microcredit program (Table 4). This finding also indicates that they wisely utilized their credit for economic activities.

Changes in ownership of assets: Almost all of the respondents agreed that they gained some assets from their business income by using credit. They managed to purchase some assets for themselves apart from spending on working capital, family, and credit repayment (Table 4). A total of $50 \%$ of the respondents reported highly positive effects on asset ownership as they owned significant assets. For instance, a few respondents mentioned that they owned land, jewelry, and vehicles. Moreover, they made some investments.

\section{Conclusions and Recommendations}

AIM is considered a successful microcredit organization. It is the largest Grameen Bank replication outside Bangladesh. Given its performance, AIM received the Best Islamic Microfinance Institution award during the 2013 and 2014 Global Islamic Finance Awards. Therefore, this study examines the performance of Islamic microcredit based on the achievement of Maqasid Al-Shariah.

The collected data were analyzed based on the achievement of the five principles of Al-daruriyyat from the perspective of Maqasid Al-Shariah. Al-daruriyyat refers to the essential need of humans, which serves as a basis for the establishment of welfare in this world and in the life thereafter. Among the five principles, the indicators of Ad-Din, Al-Nafs, $A l-N a s b$, and $A l-M a l$ improved after participating in the microcredit program, as per more than $80 \%$ of the borrowers. However, the indicators of $A l-A q l$ were not significantly 
enhanced by this program in comparison with the other principles. Moreover, numerous borrowers claimed that their involvement in the microcredit program did not help them gain additional knowledge or business skills.

Furthermore, the detailed performance assessment of microcredit and microenterprise in this study also reveals in-depth socioeconomic effects on microcredit borrowers. Specifically, borrowers with long periods of attachment to the AIM microfinance program reported higher volumes of income than those with a short period of attachment. However, this increase in income remains insufficient to meet the basic needs of these respondents. In other words, the borrowers have merely crossed the extreme poverty line through participation in such programs, but they are yet to cross the moderate poverty line.

The AIM microfinance program had a low significant effect on the savings and asset ownership of the borrowers. Although the savings volume of the borrowers increased monthly, $43.8 \%$ of these borrowers had no savings even after joining AIM. Nonetheless, a small improvement was observed in the asset ownership of the borrowers (i.e., land, jewelry, and vehicle). Among the respondents, 35\% owned land, 20\% owned jewelry, and 55\% owned vehicles.

With regard to the employment (occupation) pattern, the respondents were moderately able to partake in income-generating activities. Most of the respondents diversified their source of income by working more than one job, which also contributed to their increasing monthly income.

Based on these findings, some action plans must be developed for future expansion of AIM as a model of poverty alleviation in Malaysia. It must shift gradually toward becoming a full Islamic micro-financing institution. Given that the majority of AIM clients is Muslim, this micro-financing institution should appropriately be fully Islamic as well. Nonetheless, AIM can also serve non-Muslims as an Islamic micro-financing institution.

AIM must focus on micro-entrepreneurship development. Its institutional characteristics should also be strengthened to assist the government in achieving the organization's vision and mission, that is, poverty alleviation and the nurture and progression of entrepreneurship among the poor. AIM must also improve its financial structures and increase its outreach. It should encourage borrowers to increase their savings to facilitate sustainability and to eliminate their dependence on credit. The institution must also encourage its clients to gain some specialized knowledge or business skills to enhance the sustainability of businesses and to reduce their vulnerability. Finally, AIM must also emphasize its role assessment approach. As an Islamic microcredit institution, it must evaluate its achievements according to Maqasid Al-Shariah. We hope that this study can help this institution in this regard.

\section{Acknowledgement}

We would like to thank AIM, the Accounting Research Institute, and UiTM, in collaboration with the Malaysian Ministry of Education, for their financial support for this research project.

\section{References}


Ahmed, F., Siwar, C., \& Idris, N. A. (2011). Impact Of Microcredit Programme For The Rural Poor: Evidence From Amanah Ikhtiar Malaysia. Research Journal Of Applied Sciences, 6 (5), 290-294.

AIM (2012). Buletin Ikhtiar, Issue 1

Bakar, M.A., \& Ghani, A.A. (2011). Towards achieving the quality of life in the management of zakat distribution to the rightful recipients (the poor and needy). International $J$. Business and Social Sci., 2(4): 237-245.

Chamhuri. S., and Quinones, B., (2000). Microcredit in Malaysia: Aiming at Success: In Remenyi J. and Quinones, B., (2000). Microfinance and Poverty Alleviation: Case Studies from Asia and Pacific. Asian and Pacific Development Council. Kuala Lumpur.

Dar, H. A. (2004). Demand for Islamic Financial Services in the UK: chasing a mirage?, Economics Research Paper, no. 04-11, Loughborough University. https://dspace.lboro.ac.uk/2134/335

Dusuki,.A.W. \& Bouheraoua, S. (2011). The framework of Maqasid Al-Shariah (Objectives of the Shariah) and its Implications for Islamic Finance. ISRA Research Paper (No:22/2011).

EPU. (2010). Tenth Malaysia Plan (10MP) 2011-2015, The Economic Planning Unit, Prime Minister`s Department, www.pmo.gov.my/dokumenattached/RMK/RMK10_Eds.pdf

Gibbons, D., \& Kasim, S. (1989). Reducing Extreme Rural Poverty Through Benevolent Loans. Vol. I, Final Report of Project Ikhtiar, AIM, Centre for Policy Research, Universiti Sains Malaysia, Malaysia.

McGuire, P. B., Conroy, J. D., \& Thapa, G. B. (1998). Getting the framework right: Policy and regulation for microfinance in Asia. Foundation for Development Corporation, Brisbane. Retrieved from www.bwtp.org/publications:

Mikkelsen, B.H., Olander, K., Gubay, M.T., \& Mekonnen, W. (2008). The Swedish Civil Society Organisation/ Non-governmental Organisation Cooperation Programme, Ethiopia, 2004-2007, SIDA Evaluation 2008:30, Stockholm. Retrieved from: http://www.sida.se/publications

Nawai, N., \& Shariff, M. N. (2011). The Importance of Microfinance To The Microenterprises Development In Malaysia's Experience. Asian Social Science, 7 (12), 226-238.

Omar, M. Z., Noor, C. S. M., \& Dahalan, N. (2012). Financing An Income Generating Activities Among the Poor Rural Households: The Case of the Amanah Ikhtiar Malaysia. International Journal of Social Sciences, 1(1), 107-129.

PUNB, (2013). Perbadanan Usahawan Nasional Berhad . Retrieved from: http://www.punb.com.my/

Salma, M. (2004). A Comparative Case Study on Outreach and Impact of Ikhtiar Loan Scheme and Special Program for Hardcore Poor in Seberang Perai, Pulau Pinang. M.Phil Thesis, University Science Malaysia.

Seitanidi, M.M., \& Crane, A. (2009). Implementing CSR through partnerships: understanding the selection, design and institutionalisation of non profit-business partnerships, Journal of Business Ethics, Vol. 85, pp. 413-429

SERU. (1991). Impact Assessment Report. Research and Development Unit, Amanah Ikhtiar Malaysia. 